\title{
PHOTO-EDITORS AND PARA-PHOTOJOURNALISTS ON TWITTER. THE COMMODIFICATION OF NETWORKED IMAGES
}

\section{Editores de imagens e para-fotojornalistas no Twitter. A comodificação de imagens em rede}

\section{Foto-Editores y Para-Fotoperiodistas en Twitter. La Mercantilización de las Imágenes en Red}

\author{
Evelyn Runge \\ Principal Investigator and Assistant Professor \\ at the Institute of Media Culture and Theatre at Cologne University, Germany \\ evelyn.runge@uni-koeln.de
}

\begin{abstract}
Resumo
O serviço de microblogging Twitter ganhou importância como plataforma de troca de fotos de notícias que, em colaboração com renomados meios de comunicação, podem provocar reações imediatas de editores de imagens. As conversas no Twitter entre editores e criadores de fotos - produtores, fotojornalistas cidadãos, e para-fotojornalistas - mostram que editores de imagens recorrem a fotógrafos (amadores) para solicitar permissão para usar seu material de testemunha ocular em publicações jornalísticas. Passando em revista o espaço disputado do jornalismo visual digital entre os usuários-produtores, editores de fotos e a mercantilização de imagens em rede, apresento três cenários que mostram como termos de uso são negociados on-line - portanto, de forma publicamente visível - entre criadores de Twitpics e editores de jornais ou agências fotográficas. $\mathrm{O}$ artigo conclui com cinco resultados da relação entre editores de imagens e para-fotojornalistas no Twitter: justiça, eficiência, o valor das imagens digitais, efeitos das práticas de compartilhamento de imagens no jornalismo visual, e as práticas diárias de mídia de produtores.
\end{abstract}

Palavras-chave: Fotojornalismo. Imagens Vernaculares. Compartilhamento de Imagens.

\begin{abstract}
The microblogging service Twitter has gained importance as an exchange platform for news photos that, in collaboration with renowned media, might trigger immediate reactions from photo editors. Twitter conversations among photo editors and photo creators - produsers, citizen photojournalists, para-photojournalists - show that photo editors turn to (amateur) photographers to request permission to use their eyewitness material in journalistic publications. Reviewing the contested space of digital visual journalism between produsers, photo editors, and the commodification of networked images, I present three scenarios which exhibit how terms of use are negotiated online - hence publicly visible - between creators of Twitpics and editors of newspapers or photo agencies. The paper concludes with five results of the relation between photo editors and para-photojournalists on Twitter: fairness, efficiency, the value of digital images, effects of image sharing practices on visual journalism, and produsers' daily media practices.
\end{abstract}


Key words: Photojournalism. Vernacular Images. Image Sharing.

\section{Resumen}

El servicio de microblogging Twitter ha cobrado importancia como plataforma de intercambio de fotos de noticias que, en colaboración con medios de comunicación de renombre, pueden provocar reacciones inmediatas de los editores de fotos. Las conversaciones en Twitter entre editores y creadores de fotos - produsuarios, fotoperiodistas ciudadanos, para-fotoperiodistas - muestran que los editores de fotos se dirigen a los fotógrafos (amateurs) para pedirles permiso para utilizar su material presencial en las publicaciones periodísticas. Revisando el espacio en disputa del periodismo visual digital entre los produsuarios, los editores de fotos y la mercantilización de las imágenes en red, presento tres escenarios que exhiben cómo se negocian los términos de uso en línea - por lo tanto, públicamente visibles - entre los creadores de Twitpics y los editores de periódicos o agencias fotográficas. El artículo concluye con cinco resultados provisionales de la relación entre editores de fotos y parafotoreperiodistas en Twitter: la equidad, la eficiencia, el valor de las imágenes digitales, los efectos de las prácticas de intercambio de imágenes en el periodismo visual y las prácticas mediáticas cotidianas de los produsuarios.

Palabras clave: Fotoperiodismo. Imágenes Vernáculas. Intercambio de Imágenes.

\section{INTRODUCTION}

Circulation and image sharing have become everyday media practices; former boundaries between professional photojournalists and amateur photographers have blurred either by the professional context in which the actors work or by citizen photojournalism. This is evident as evinced on the microblogging platform Twitter, where images published by eyewitnesses in the wake of natural disasters or terrorist attacks can go viral and through further dissemination by professional journalistic photo agencies or newspapers, alter the context from one rooted exclusively in social media to one encompassing myriad platforms. Indeed, the circulation of digital images takes place across specific platforms, media ecologies, and professional fields (RUNGE, 2020a). Images as popular visual media are networked and based on socio-cultural and socio-technical interactions that connect technology, society, and individuals - so-called networked images (GÓMEZ CRUZ Cruz \& MEYER, 2012; RUBINSTEIN \& SLUIS, 2008).

As part of my research project "Behind the Digital Image. Photographs on Community Platforms and on Twitter as Repositories for Machine Learning and Journalistic Publications", I investigate conversations about rights of use and broader legal, ethical, and social questions of digital image circulation, the ecology of social media - here specifically 
the microblogging service Twitter - and practices of image sharing. ${ }^{1}$ Twitter is suitable as an object of study because the platform that it employs proves significant for researching newsworthy photos. At the same time, the intertwining of new ways of dealing with rights clarification and the sharing economy raise questions about power imbalances, as the requesting photo editors have an advantage over amateur photographers concerning knowledge about copyright law and rights of use. Initially, it seemed only logical that the (often internationally) sensational events such as terrorist attacks or natural disasters would be of primary interest. Still, the data available so far shows that local events - such as weather phenomena - can also result in requests from journalistic media companies.

According to Alfred Hermida, Twitter is a source of news that can be described as an "ambient news network" (HERMIDA, 2010) in which users emerge as non-professional parajournalists. According to Axel Bruns, this type of news network "enables serendipitous news discovery and transitions to focussed social news curation especially when acute breaking news events occur, or within dedicated longer-term networks of topic-focussed social news curators" (BRUNS, 2018, p. 309). Other studies confirm that eyewitness material is used by journalistic media companies, photo agencies and photo editors in unforeseen newsworthy events - and that photojournalists take over the subsequent reporting as soon as they arrive on the scene. In events such as the 2010 earthquake in Haiti, it can take several days for nonlocal professional journalists to arrive at the scene (after scheduling visa, travel, stringers, fixers, informants, etc.). As foreign correspondent networks have been thinned out or cut altogether in recent decades, social networks have become valuable - and comparably inexpensive - research tools for journalists and social media editors who do not even have to leave their desks in the Global North to suggest on-the-ground reporting.

Previously published media and communication studies on photojournalistic images on Twitter have neglected to make any distinction when considering the source of the digital image - i.e. as emerging from professional or citizen photojournalism. Instead, photos and research on them are increasingly assigned to platforms, as if the nature of the source professional, semi-professional or amateur - were self-explanatory. To rectify this conceptual

\footnotetext{
${ }^{1}$ Funded by the DFG German Research Foundation - grant number 421462167 (https://gepris.dfg.de/gepris/projekt/421462167). - An earlier version of this paper was presented at IAMCR 2020 conference, and I thank the discussants for their valuable feedback. I am also grateful for the support of IAMCR's Visual Culture Working Group, namely the chair Denize Araujo. I thank Stephan Packard for the opportunity to discuss my work at the research colloquium at the Institute of Media Culture and Theatre at Cologne University, Germany, and Anna Prianka Schmidt for supporting the data collection. - Parts of this paper will also be published in German (Runge, 2021a, 2021b).
} 
lapse, future theorisation of the digital image in the journalistic context ought to distinguish more stringently between the terms photojournalism, citizen photojournalism, and visual journalism, among others. Indeed, an actionable theory which addresses the terms citizen (photo) journalist and para (photo) journalist via intuitive use is long overdue. Some nascent conceptual work has already been established, the latter term being used repeatedly ever since the publication of Seth Lewis' paper in 2012, albeit without any decisive elaboration (Lewis, 2012). Therefore, the next chapter proposes elaborations of these terms to help further the theory of the digital image.

This paper is specifically interested in the following aspects: What events do Twitter photos from eyewitnesses depict and how (image content)? What criticism is there of the approach taken by photo editors and news and photo agencies (free assignment of unlimited rights of use)? After a brief description of the existing literature on photojournalism on Twitter and an attempt at a theoretical connection, the article concentrates on three scenarios that seem relevant:

1. negotiating dissemination through simple yes-no conversations and more complex social media release forms.

2. publication and transformation of a tweet into a 'journalistic' story.

3. the formation of (individual) protest against unpaid work.

In the notes, readers will find links to the images discussed, which they can access independently. As this project presentation is a work in progress, the results are to be understood as intermediate aspects and not as conclusive findings. The study is exploratory in nature; as it is an initial survey, it is not intended to be complete or representative: The examples focus on photos that are relevant to journalistic contexts. There are many similar examples on Twitter in which private individuals in which private individuals request permission from producers to use their photos (BRUNS, 2006, 2008), for example as header of their own Twitter account, simply because they like the pictures. There are also requests from commercial companies to use the images in their own advertising, requests from sports clubs or non-governmental organisations (NGOs) such as environmental protection or disability associations that often have little or no budget for image fees. All these stakeholders, like photo editors, aim to acquire image material from so-called user-generated content (UGC) to reduce their own costs compared to commissioned photos on the one hand, and on the other hand to increase the produsers' loyalty, and, at best, identification with the organisation and its goals by engendering a feeling of nobility. However, this paper's 
contribution is limited to conversations between produsers and photo editors and thus leaves considerable room for potential future research (RUNGE, 2021b, 2021a).

After presenting the rise of digital eyewitness material and wrapping up briefly main events since 2004, this paper proposes a more distinct differentiation of terms such as produser, citizen (photo) journalist, para-photojournalist, and non-human eyewitnesses such as drones. It briefly reviews the contested space of digital visual journalism between produsers, photo editors, and the commodification of networked images.

\section{THE RISE OF DIGITAL EYEWITNESS MATERIAL}

After the December 2004 tsunami in Southeast Asia, newsrooms and news agencies were dependent on eyewitness material. The digital citizen journalist was born, according to BBC's reflection in 2014: “[i]t was the tsunami on 26 December 2004 which led to a significant shift in the way we dealt with these contributions. Eyewitness accounts told the story where we did not have correspondents on the ground" (TAFT, 2014). In the Germanspeaking world, the online offerings of Spiegel and taz - die Tageszeitung provided some images with a warning to recipients: The images could be disturbing, which is why they were covered in black, and recipients could only click away the warning after actively confirming that they wanted to see the images (cf. RUNGE, 2012).

In the period after 2004, many examples of the use of eyewitness footage, especially from dangerous and unforeseeable events such as terrorist attacks in urban areas, natural disasters such as earthquakes, and civilian protests against undemocratic regimes and pro human rights, have been covered in the academic literature. The list here is not exhaustive and only reflects a small part of the events: The London Underground bombing (2005); Hurricane Katrina (2005); the Virginia Tech shooting (2007); the terrorist attacks in Mumbai (2008); the post-election demonstrations in Iran, where Neda Agha-Soltan's death led to widespread coverage, including via YouTube videos (2009); the earthquake in Haiti (2010); the Arab Spring (2011 onwards); natural and nuclear disasters in Japan (2011: Earthquake, Tsunami, Fukushima), the Boston Marathon bombing (2013); the Black Lives Matter initiatives (since 2013); the attacks in Brussels, Nice and Munich (2016) (ALI \& FAHAMY, 2013; ALLAN, 2014; BRUNS \& HANUSCH, 2017; CARNEY, 2016; CHATELAIN \& ASOKA, 2015; DAVE, FRIEDSON, MATSUZAWA, SABIA, \& SAFFORD, 2020; HALVERSON, RUSTON, \& TRETHEWAY, 2013; HÄNSKA AHY, 2016; HERMIDA, LEWIS, \& ZAMITH, 2014; HOWARD et al., 2011; LOTAN et al., 2011; MORTENSEN, 2015; 
RAUCHFLEISCH, ARTHO, METAG, POST, \& SCHÄFER, 2017; RUBINSTEIN \& SLUIS, 2008). It is likely that research will be published in the coming years on eyewitness photos on social media of the pro-democracy demonstrations in Hong Kong (2019/20), the protests following George Floyd's death at the hands of a police officer (2020), the ammonium nitrate explosion in the port of Beirut known as the Beirut Blast, which destroyed parts of the Lebanese city (2020), as well as the demonstrations in Belarus against President Lukashenko (2020-present), the protests for Alexey Navalny's release in Russia (2021), the storming of the Capitol in Washington D. C. (2021) and the protests against the military coup in Myanmar (2021). All these events and instances of social upheaval have been widely shared on social media, since free press is partly restricted in the countries mentioned and produsers have taken over (citizen) journalistic tasks.

A comparative reading of the research literature reveals that various terms are used synonymously to describe the visual engagement of citizens, including for example produser/produsage (according to Bruns a hybrid of producer and user, based on Toffler's prosumer, a hybrid of produser and consumer (TOFFLER, 1996)), as well as for example citizen (photo) journalist, citizen-led imagery, citizen (visual) reportage, citizen generated alternatives, accidental photojournalism or parajournalist (ALLAN \& PETERS, 2015a, 2015b; PETERS \& ALLAN, 2016). Often the word 'photo' does not appear in the term itself, indicating the lack of respect for photography as journalist jargon in its own right within editorial work contexts.

To reduce this gap, this article proposes to distinguish and define the terms more clearly and to integrate different perspectives which are usually considered separately in visual journalism. This is exemplified by produser, citizen (photo) journalist (and variants such as citizen generated alternatives, citizen led imagery, citizen visual reportage), paraphotojournalist and robot eyewitnessing/non-human photography. At the same time, it should be borne in mind that the conceptual juxtaposition indicates a transformation phase that is currently still ongoing. These terms can be coined as auxiliary constructions, as they are designations assigned by academics and journalists, yet do not reflect the self-image of the produsers.

a) Produser - according to Bruns (BRUNS, 2006, 2008) - is a neutral generic term, as is user generated content (UGC). This paper proposes to use the term produser as openly as possible to frame persons who produce eyewitness material: The term produsers does not distinguish between word and image contributions. Moreover, produser says nothing about 
the self-image of the creators or their intention(s). In editorial departments, terms can be used even more specifically, for example Williams et.al. point out that UGC in the BBC is understood as audience content and explicitly "eyewitness footage or photos, accounts of experiences, and story tip-offs" ("usually denotes only this kind of material", (WILLIAMS, WARDLE, \& WAHL-JORGENSEN, 2011, p. 85)). Less common are the terms user generated journalism, audience content, and audience material.

b) Citizen (photo) journalist, citizen generated alternatives, citizen led imagery, citizen visual reportage: Following Ariella Azoulay, the term citizen is based on democracy theory and has the potential to be explored in digital citizenship, visual (media) ecology and visual (media) ethics. Lucaites and Hariman also develop concepts of the visual public sphere and visual democracy as civic performance. They refer primarily to activists at civil society demonstrations for human rights, democracy, pluralism, and civil liberties. The citizen journalist thus represents an inclusive attempt. Citizen visual reportage is conceptually linked to the journalistic genre of reportage, which addresses conflicts, including internal conflicts of one or more protagonists, and which requires a subjective attitude on the part of the reporter, which becomes visible to recipients in the article or image (AZOULAY, 2008, 2010a, 2010b, 2015; HARIMAN \& LUCAITES, 2011, 2016; RUNGE, 2020b). So far, citizen journalist has often been used apolitically - in contrast to Azoulay's activating understanding deriving from democracy theory. I therefore propose a future use of citizen photojournalist based on Azoulay, Lucaites and Hariman.

c) Para-photojournalist: Lewis introduces the term parajournalist in 2012:

With the introduction of citizen journalism (ALLAN/THORSEN 2009) - in other places referred to as open-source (DEUZE 2001), participatory (BOWMAN/WILLIS 2003), grassroots (GILLMOR 2004), and networked (JARVIS 2006; BECKETT/MANSELL 2008) journalism - Carey's vision for a co-creative, conversational public suddenly became possible, at least for the digitally connected; with this too, however, came the spectre of parajournalists threatening the jurisdictional claims of professionals by fulfilling some of the functions of publishing, filtering, and sharing information (LEWIS, 2012, p. 850).

I advocate for the use of the term para-photojournalist: It captures the ambiguity of the in-between, in which produsers designated as citizen journalists find themselves, namely between attributions by editorial offices and their self-image. The term para-photojournalist may not possess any connotation suggestive of ambition for their own journalistic activity but rather becomes ambitious through editorial contextualisation. At the same time, the term 
shows a disruptive uncertainty of professional actors in journalism, as can be seen from Lewis' quote.

d) Robot eyewitnessing, drone journalism, non-human photography: Gynnild uses drone journalism as an example of robot eyewitnessing (GYNNILD, 2014), which is currently transforming visual journalism while also serving as a disruptive innovation. Following Zelizer (ZELIZER, 2007, p. 20), eye witnessing is understood as "a report, as a role, and as a technology". Gynnild argues that user-generated content contributes to "expanding visual transparency in society, the visual disclosure of issues, places, and events previously not seen" (GYNNILD, 2014, p. 335) - drone journalism serving as an example of "the visual conquering of formerly unwatched realities" that force innovation in journalism (GYNNILD, 2014, p. 341). It is noticeable that in the Anglo-American region a whole portfolio of mediation, teaching, practice, and theory of drone journalism has emerged, while for instance in German-speaking countries this type of reporting is hardly considered, at least in academic monitoring and practical teaching. It is true that drones are being increasingly used for aerial shots in feature or nature films, partly because lower costs compared to manned aircraft. The cost issue is one Gynnild elaborates upon relatively prominently in her paper. Thus far, however, this has not led to any deeper engagement or empirical-ethnographic exploration of robot eyewitnessing as part of visual journalism for instance in the German-speaking world.

The terms explored thus far have in common that they mostly refer to visual and eyewitness material - it is not primarily about texts written by readers and recipients. This is also due to reasons of efficiency: There is too much editing and editorial work that cannot or does not want to be done, especially in condensed work contexts such as in everyday online production. It is striking that terms like accidental journalism or parajournalism have pejorative connotations, in Lewis' words a sense of threat to journalists from non-professional competition (LEWIS, 2012, p. 850). Produsers and citizen journalists are rarely thanked and appreciated publicly; Andy Carvin's actions marked an exception when he made explicit mention of his (purely digitally networked) informants who helped him with tips, translations, and verification during the Arab Spring: "I don't just have Twitter followers. You're my editors, researchers \& fact-checkers. You're my news room. And I dedicate this award to you."2 Carvin received a Shorty Award in 2012 for his journalistic use of Twitter: His thanks can be interpreted as indicative of how he regards the activists with whom he has worked at a

\footnotetext{
${ }^{2}$ https://twitter.com/acarvin/status/184424440757624832, 27.3.2012
} 
distance, namely, as being on a par with himself (cf. RUNGE 2021b). Here one can rightly speak of citizen (photo) journalism and citizen visual reportage.

How exactly do produsers see themselves? How do they assess their contribution to an open visual participation culture? What has motivated them to do so? And would they describe their contributions as 'accidental (photo) journalism' and thus non-intentional and incidental? All these questions remain as yet unresolved. In a study on open-source community reporting, Aitamurto found out that recipients donate in order to establish new journalistic formats or products - but see journalists as experts for the conceptual and contentrelated work. And not at all as competition:

There is a gap between the expectations of the reporters concerning the reader's participation and the reality of the interaction with the community members. The reporters are hoping to receive contributions in the form of leads and tips, but readers are not interested in submitting them. They perceive the journalist as the expert on the topic, and therefore, he or she needs to do the work. (AITAMURTO, 2011, p. 441).

Follow-up studies focusing on visual journalism could use the typologies proposed here to ask produsers to clarify their self-image and, if necessary, to suggest a change in selfimage in the interplay with technological innovations. Thus far, the conceptual designations and attributions have been made by editors and academics.

\section{VISUAL JOURNALISM: A CHART OF DISRUPTIVE INNOVATIONS}

Visual journalism is an incredibly broad field that includes photojournalism, moving images, data visualisations, infographics, illustrations, layout, user experience and design, videos, and the use of stock photography. Each of these sub-areas has peripheries that cannot be illuminated in this article; we can only refer to photojournalism that reaches audiences that are not congruent with the recipients of a particular newspaper or online publications in museums, at photo festivals, in workshops and documentary films about photojournalism; also, because (touring) exhibitions, festivals, and workshops are increasingly international and multilingual. It goes without saying that data visualisations and infographics also exist outside of (visual) journalism - in journalism itself they have only been common since just before the turn of the millennium. One could say that infographics were disruptive innovations in journalism about 20 years ago and have remained an integral part ever since.

Following Machin/Polzer, visual journalism is a multimodal theory-practice approach to photojournalism, design, moving image formats, et cetera (MACHIN \& POLZER, 2015). The diagram - on the next page - also depicts the subsystems; disruptions through platforms, 
algorithm cultures, non-human photographic technology are inserted like spikes into the bubble of journalistic subsystems. However, recipients and produsers are left out, though they are - as Newton rightly argues - part of an "ecology of the visual" (NEWTON, 2009, 2012, pp. x, 172). Follow-up research would do well to create a link to media ecology in order to advance an inclusive perspective that includes visual literacy, media literacy and data literacy.

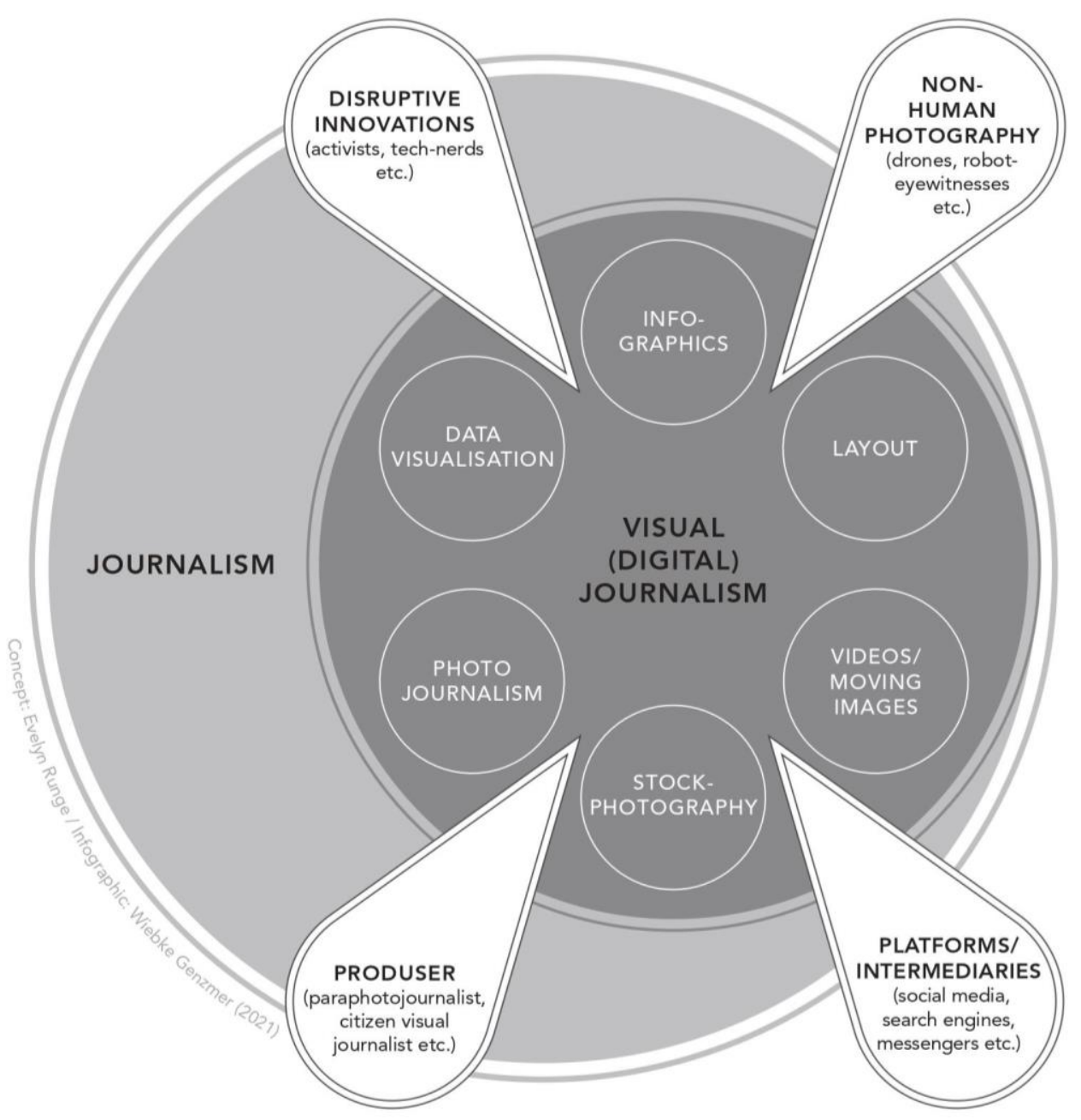

Chart 1 - Digital Visual Journalism and its Stakeholders

Source: Concept by Evelyn Runge, Infographics by Wiebke Genzmer (2021)

\section{THE CONTESTED SPACE OF PRODUSAGE - THREE SCENARIOS}

After the attack on the airport (and later metro stations) in Brussels in 2016, produser Daniela Schwarzer published a photo on Twitter showing a part of the airport building with light smoke above it. In the accompanying text, Schwarzer mentions the place, time, and the impression of having heard two explosions. Within a noticeably short time, editorial offices asked in reply tweets whether they could use this photo in their media, to which Schwarzer replied affirmatively. This example aptly illustrates how, in extraordinary events such as a 
terrorist attack, the first eyewitness material attracts the maximum attention of photo editors. Particularly interesting is the discrepancy between simply held tweet-length requests and the Associated Press (AP) social media release form, which amounts to a buy-out contract. ${ }^{3}$

Based on this observation, the corpus is created in an open-ended fashion in terms of time and topic through Twitter questions such as "may we use your photo?" or "can we use your photo?" as request standards. The photos and conversations are archived and evaluated. In a second step, interview requests will be made to authors and photo editors to learn more about the motivation for publishing the images' online, their reactions to editors' requests, their legal understanding of the request and, if applicable, the social media release form. For photo editors, questions about the status of UGC, ethical problems and journalistic needs for eyewitness material will be central. The aim is to test the hypothesis that the self-image of produsers, citizen photojournalists, para-photojournalists and the likes differs from that of professional photojournalists - and that they operate based on the media practice of free image sharing rather than on professional approaches involving negotiating fees and restrict the use temporally and spatially.

\subsection{Scenario 1: Negotiating Dissemination through Simple Yes-No Conversations and More Complex Social Media Release Forms}

Many, perhaps even most of the requests from photo editors are accepted by the creators with a simple "yes". Some produsers request to be sent the link after further dissemination of their photo, as Benjamin Feldman did. Picturing Montgomery Bart Tube Station in the dark after a power outage, the US news agency Associated Press, which has repeatedly attracted attention in recent years for its employees sending so-called social media release forms within a tweet, sent a declaration of consent as a digital image. Feldman was contacted by Amanda Lee Myers, who has incorporated her media affiliation into her Twitter handle: @AmandaLeeAP. She wrote on April 21 ${ }^{\text {st }}, 2017$, about two hours after Feldman posted his Twitpic: "Hi, I'm an @AP reporter and we'd like to use your photo. If you agree, can u reply that you shot the photo and agree to the attached terms?"4

The attached AP Social Media Release Form is a consent form tailored for social media that transfers the rights to use the requested image material temporarily and spatially, including for future, yet unknown forms of media and distribution as well as AP's right to

\footnotetext{
${ }^{3}$ https://twitter.com/kdombsadof/status/712179596309954560, 22.3.2016

${ }^{4}$ https://twitter.com/BWFeldman/status/855495708622766080, 21.4.2017
} 
license the image material to others. (These licenses are usually made at royalty rates, meaning that AP would generate revenue from the visual material acquired free of charge from eyewitnesses). In addition, produsers must confirm that they own the copyright and that they release AP from any responsibility. Only four minutes after AP's request, Feldman replies: "Yes, but please include an attribution to Benjamin W. Feldman / @BWFeldman on the photo or directly below the photo in all instances. Thanks."

It is striking that Feldman explicitly refers to his photo credit and emphasises that his name must be used as the author "in all instances". Even though Feldman does not go so far as to ask for a fee for the use of the image or at least for a supporting link, the attention on his part to the author's credit suggests that he understands there is a general copyright or copyright under US law. Scenario 3 will show that the social media release form from AP has been increasingly criticised as an aggressive rights transfer strategy by users, and that $\mathrm{ABC}$ News blatantly admits paying no fees for citizen photojournalists work. Still, rights transfers are often executed with much greater ease via simple yes/no correspondences in the form of tweets - which have equally far-reaching legal consequences as social media release forms.

\subsection{Scenario 2: Publication and Transformation of a Tweet into a Journalistic Story}

On October $2^{\text {nd }}, 2019$, Aaron Katzman tweeted a photo from a runway, apparently taken out of a plane's window. The upright picture shows on its lower half the empty runway, and behind the airport's buildings, an emerging pillar of dark smoke covers the sky. Katzman writes: "According to our pilot a plane crash on the runway in Hartford has closed the airport and has everyone scrambling." Immediate requests for permission of usage come from Fox61News, CNN, ABC Connecticut, among others. The New York times' photo editor Andrew Hinderaker says: "hi Aaron, can NYT use this with our coverage? Thank you."6 Generously Katzman permits the use with a short "sure" - as he answered most of the requests. But only Hinderaker sends a link to NYT's coverage, featuring Katzman's photo. (Since the incident happened in 2019, the photo nowadays is transparently marked with "Published 2019", so nobody thinks about an actual event.) In landscape format, Katzman's photo is shown and credited: "An antique military plane carrying 13 people crashed while trying to land at Bradley International Airport in Connecticut. Credit: Aaron Katzman" (PAYBARAH \& NEGRONI, 2019). The image then turns into moving footage,

\footnotetext{
${ }^{5}$ https://twitter.com/aaron_katzman/status/1179395688628707336, 2.10.2019

${ }^{6} \mathrm{https}: / /$ twitter.com/ahinderaker/status/1179402278308126721, 2.10.2019 
accompanying a rather long article about a World War II-vintage bomber carrying 13 passengers of whom seven were killed in the crash following an emergency landing shortly after take-off from the same airport.

In this case, the citizen photojournalist's footage is used as eyewitness material with credit, albeit without featuring him as part of the story. In other cases, a tweet and a Twitpic's produser is turned into a journalistic story itself, as briefly shown in the following: On March $28^{\text {th }}, 2020$, Josh Anderson tweeted a photo of the back of a girl looking through a glass door and holding a note block or clipboard in her left hand. She looks at a man kneeling in front of the door next to a flipchart and pointing at it. Josh Anderson writes:

My 6th grader emailed her math teacher for some help so he came over \& worked through the problem with her on our front porch. @Chriswaba9, our neighbour, MMS teacher \& MHS Wrestling Coach. \#KidsFirst @MadisonMSNews@MarkOsports@dakotasportsnow @dakotanews_now@stwalter20.7

Like Feldman, Anderson addresses the tweet to local news outlets, and he discloses the teacher's name via his twitter name @Chriswaba9. Whether he did so in consultation with him is impossible to ascertain. In addition to thousands of likes, a user with the twitter name @ cherinicita responds: "Hello Josh! I work for Fox TV stations and we absolutely love this story! May we use your photo on all platforms until further notice, with a courtesy to you of course? Please let me know. Thanks so much!” Anderson responds positively with a request for a proof link: "You sure can. Thanks for your interest. Please send me the link to your story so we can view it as well!" 8 A few hours later, the Fox TV employee sends a link to the website where the article was published under the headline "Math teacher brings over whiteboard to help student through glass door" (N., 2020). In the very first sentence, the author - who is not named - refers to the Corona crisis, still new in spring 2020: "Even during a pandemic, some teachers are showing that they're still willing to go above and beyond for their students." The five paragraphs that follow merely elaborate on what Anderson says in his two-sentence tweet - Fox TV even knits a plot out of it: "It wasn't a long trip for Waba Anderson says he happens to be their neighbour." By using phrases like "Anderson says", Fox TV gives the impression of having spoken to Anderson. The article ends with the embedded tweet and phone number of the COVID-19 emergency centre in Florida. The article sets Anderson's photo as a positive example of a maths teacher helping his student during the pandemic (N., 2020).

\footnotetext{
${ }^{7}$ https://twitter.com/DakSt8Football/status/1243687140799766532, 28.3.2020

${ }^{8}$ https://twitter.com/DakSt8Football/status/1245376030497558534, 1.4.2020
} 
The example shows how journalistic 'stories' are generated from tweets with little information. These image careers in journalistic media suggest that - as in Anderson's case the textual content of the tweet can become more important than the image, which only acts as an eyecatcher. The present example shows that hardly any further journalistic research was done by the editorial staff beyond the information given in the tweet. In this respect, the resulting report is to be understood primarily as cheap user-generated content. The author of the image, Anderson, was informed of the publication via link at his own request - an exception so far in this project's data collection.

\subsection{Scenario 3: Formation of (Individual) Protest against Unpaid Work}

Not all users grant certain (or all) rights to use their photos for distribution in journalistic media, news, or photo agencies - neither in the case of direct requests nor in the case of general calls to send in photos, as practised by CNN in July 2019, for example. In a tweet, CNN asked current and future eyewitnesses to submit pictures from a natural phenomenon: "Are you affected by Hurricane Barry? When it's safe, text, iMessage or WhatsApp your videos, photos and stories to CNN [...]." This request was lambasted by a user named John Robertson: "Just wow. I'm making sure from now on in journalism class I teach my kiddos to say NO to 'hello I'm from X May we use your photo with credit to you of course' tweets. They're a business folks, make them PAY YOU for your content they're going to make money on." 9 The user's criticism refers solely to media companies and their assumed profits from users' images and content. However, Robertson overlooks the fact that he himself also generates revenue and profit for Twitter through his engagement.

What Robertson and other produsers address individually rarely finds its way out of the Twittersphere: namely, criticism of the power imbalance between media companies and para-photojournalists. In May 2020, technology-focused online publications like Digital Photography Review and Techdirt gathered outspoken criticism on the Associated Press' social media release forms from the Twitter- and blogosphere. Essentially, they summarise a thread by Mike Dunford - a lawyer, according to his own Twitter bio - in which he explains in detail the AP Social Media Release Form and interprets it in terms of its legal implications. It is likely that AP has used this consent form since 2015; Jay Marshall Wolman points to it in a reply tweet to Dunford. No other user has added an older version, and my own search did not reveal any earlier finds, so it can be reasonably assumed that AP likely started this

\footnotetext{
${ }^{9}$ https://twitter.com/Cru33/status/1150183017744424962, 14.7.2019
} 
practice in 2015. Dunford formulates the core criticism in a single tweet - the planned procedure, legally secured by AP lawyers, for which the AP (photo) editors were trained, the clarification of rights of use, copyright and written consent: "So @AP reporters and editors have clearly been trained to do three things before using anything on social media: (1) Ask for permission to use it; (2) Confirm that the person giving permission took the photo/video; (3) Get them to agree to a release presented as an image." ${ }^{10}$ Aspect 3 is particularly interesting: the contract is presented as a digital image. Unlike contracts in paper form or PDF, it is not intended that authors negotiate this contract.

Dunford calls AP's way of formulating and enforcing legal wishes "abusive and unethical". In his opinion, the second paragraph of the AP Social Media Release Form is even more problematic than the first: the authors release AP from any legal responsibility - if a lawsuit is filed, the produsers bear all risk. Apparently, AP never reacted to the accusations presumably also out of knowledge of its own economic strength. AP is not alone in requesting perpetuity for use on all platforms and future, yet unknown media. Another striking example comes from ABC News. Referring to Aaron Katzman's aforementioned example of the plane crash in Hartford, ABC News' Fergal Gallagher sent a short request and included the link to ABC News' "Image/Video Solicitation and Rights Confirmation Terms" (ABC NEWS, 2019). Gallagher's tweet read: “I'm with ABC News. Did you take this image or otherwise own all rights to it? If so, do you agree to allow $\mathrm{ABC}$ News and its licensees to use and distribute without restriction in all media? Full terms: http://abcnews.com/terms."11

Whereas the tweet summarizes temporary and spatially unlimited use, the full terms detail the demand but also state in the last paragraph: "You understand that you will receive no payment or royalty for any use under this agreement; that $\mathrm{ABC}$ is under no obligation to use, edit or distribute the material; and that you have no right to inspect or approve any use of the material."(ABC News, 2019). This explicit expression of reluctance to pay for work is quite rare but demonstrates rather clearly the policy of media companies towards produsers, citizen photojournalists, para-photojournalists and the likes.

Rather remarkably, data collection has thus far yielded neither replies nor re-tweets with edits of the digital contract image. If produsers do not want to enter into this contract, it is more common not to reply at all than to explicitly write "no". Considering this knowledge, it is exceptional that a Twitter user nicknamed or abbreviated 'Barry' responded blatantly,

\footnotetext{
${ }^{10} \mathrm{https}: / /$ twitter.com/questauthority/status/1262048571026739200, 17.5.2020

${ }^{11} \mathrm{https} / / /$ twitter.com/gallagherfergal/status/1179401981087105025, 2.20.2019
} 
"Sorry, I'd rather you didn't", when MetroUK's Anas Chowdhury requested permission to publish 'Barry's' Twitpics of areas affected by recent snowfall on December $29^{\text {th }}, 2020 .{ }^{12}$ Produsers rarely or never set limits, for example by negotiating contracts on the scope of use, royalties, and (bestseller) remuneration. This is because, as dispersed produsers, they do not unionize. Secondly, produsers are largely uninformed as regards their legal rights as creators because they do not see themselves primarily as journalists, and because they are used gratis use of photos by social media. The outrage exhibited both in the comments under Dunford's thread and the respective blog articles is understandable, yet likely remains a far cry from any actionable impetus to advocate their own rights. Thirdly, as 'Barry's' example shows, it is still possible to resist requests individually.

\section{CONCLUSIONS}

Unintentionally produced and newsworthy eyewitness material is a resource of increasing interesting for monetary exploitation by picture and news agencies as well as (also locally operating) journalistic media companies. In addition to the legal consequences listed above such as non-remuneration and the assumption of any risk by the authors, there are also ethical considerations: How much do journalistic media companies harm themselves through these rigorous buy-out contracts? Are media companies - constitutionally enshrined and having public mandate in democracies - leading by example, willfully and consciously thriving on unpaid services such as produsers' work?

The results of my project can be identified as follows:

Fairness: When picture editors ask produsers if they can use their picture, they do so out of a legal need to clarify the rights of use and copyright. Requests can be interpreted as an act of fairness towards the produsers, even though they are not treated as equal business partners, as clearly seen in the AP's and ABC News' Social Media Release Forms.

Efficiency and effectiveness: By sending social media release forms, which produsers are supposed to confirm by a reply tweet, photo editors can very easily and effectively obtain permission to distribute and share and/or sell the images. The only requirement is that produsers reply to the message.

\footnotetext{
${ }^{12}$ https://twitter.com/Mr_B_OB/status/1344024709797720065, 29.12.2020
} 
The value of the images: The consent forms requested by photo editors correspond to buy-out contracts, although the requesting media companies, news, and picture agencies have the right of profit-oriented re-licensing explicitly granted to them. In this procurement of picture material (and this is what the requests from photo editors to Twitter produsers are all about), media companies exploit the ignorance of produsers.

Effects of daily media practice: Produsers find themselves in a double role - as media spectators and as image producers. The spontaneous and generous consent to use their images results from everyday digital image sharing as a widespread and unquestioned media practice.

Overall, despite what seems to be free image sharing within an online participatory culture, the commodification of networked images is obvious - through platforms and intermediaries like Twitter as well as media companies like AP and ABC News, to name only a few. As the graphic has further exemplified, the relationship between the stakeholders in digital visual journalism is contested. Follow-up research could also be conducted in the field of moving images such as videos as well as on the use of bots for image acquisition.

\section{REFERENCES}

ABC News. (2019, January 17). Image/Video Solicitation and Rights Confirmation Terms-ABC News. Retrieved May 28, 2021, from https://abcnews.go.com/Press_Release/social-mediaimagevideo-solicitation-rights-confirmation-guidelines/story?id=60443540

Aitamurto, T. (2011). The Impact of Crowdfunding on Journalism: Case study of Spot.Us, a platform for community-funded reporting. Journalism Practice, 5 (4), 429-445. doi: $10.1080 / 17512786.2010 .551018$

Ali, S. R., \& Fahmy, S. (2013). Gatekeeping and citizen journalism: The use of social media during the recent uprisings in Iran, Egypt, and Libya. Media, War \& Conflict, 6 (1), 55-69. doi: $10.1177 / 1750635212469906$

Allan, S. (2014). Witnessing in crisis: Photo-reportage of terror attacks in Boston and London. Media, War \& Conflict, 7 (2), 133-151. doi: 10.1177/1750635214531110

Allan, S., \& Peters, C. (2015a). The 'Public Eye' Or 'Disaster Tourists': Investigating public perceptions of citizen smartphone imagery. Digital Journalism, 3 (4), 477-494. doi: 10.1080/21670811.2015.1034517

Allan, S., \& Peters, C. (2015b). Visual truths of citizen reportage: Four research problematics. Information, Communication \& Society, 18 (11), 1348-1361. doi: 10.1080/1369118X.2015.1061576

Azoulay, A. A. (2008). The civil contract of photography. Cambridge: Zone Books.

Azoulay, A. A. (2010a). Getting Rid of the Distinction between the Aesthetic and the Political. Theory, Culture \& Society, 27 (7-8), 239-262. doi: 10.1177/0263276410384750 
Azoulay, A. A. (2010b). What is a photograph? What is photography? Philosophy of Photography, 1 (1), 9-13. doi: 10.1386/pop.1.1.9/7

Azoulay, A. A. (2015). Civil Imagination: A political ontology of photography. Brooklyn, NY; London: Verso Books.

Bruns, A. (2006). Towards produsage: Futures for user-led content production. Proceeding of the 5th international conference on cultural attitudes towards technology and communication; 275-284. School of Information Technology.

Bruns, A. (2007). The future is user-led: The path towards widespread produsage. Proceedings of perthDAC 2007: The 7th International Digital Arts and Culture Conference; 68-77. Curtin University of Technology.

Bruns, A. (2018). Gatewatching and news curation journalism, social media, and the public sphere. New York, Bern, Berlin, Bruxelles, Oxford, Wien: Peter Lang Publishing Inc.

Bruns, A., \& Hanusch, F. (2017). Conflict imagery in a connective environment: Audiovisual content on Twitter following the 2015/2016 terror attacks in Paris and Brussels. Media, Culture \& Society, 39(8), 1122-1141.

Carney, N. (2016). All Lives Matter, but so Does Race: Black Lives Matter and the Evolving Role of Social Media. Humanity \& Society, 40 (2), 180-199. doi: 10.1177/0160597616643868

Chatelain, M., \& Asoka, K. (2015). Women and Black Lives Matter. Dissent, 62 (3), 54-61. doi: $10.1353 / \mathrm{dss} .2015 .0059$

Dave, D. M., Friedson, A. I., Matsuzawa, K., Sabia, J. J., \& Safford, S. (2020). Black Lives Matter Protests and Risk Avoidance: The Case of Civil Unrest During a Pandemic (No. w27408). National Bureau of Economic Research. doi: 10.3386/w27408

Gómez Cruz, E., \& Meyer, E. T. (2012). Creation and Control in the Photographic Process: IPhones and the emerging fifth moment of photography. Photographies, 5 (2), 203-221. doi:

$10.1080 / 17540763.2012 .702123$

Gynnild, A. (2014). The Robot Eye Witness: Extending visual journalism through drone surveillance. Digital Journalism, 2 (3), 334-343. doi: 10.1080/21670811.2014.883184

Halverson, J. R., Ruston, S. W., \& Trethewey, A. (2013). Mediated Martyrs of the Arab Spring: New Media, Civil Religion, and Narrative in Tunisia and Egypt. Journal of Communication, 63 (2), 312332. doi: $10.1111 /$ jcom. 12017

Hänska Ahy, M. (2016). Networked communication and the Arab Spring: Linking broadcast and social media. New Media \& Society, 18 (1), 99-116. doi: 10.1177/1461444814538634

Hariman, R., \& Lucaites, J. L. (2011). No caption needed: Iconic photographs, public culture, and liberal democracy. Chicago, IL: The University of Chicago Press.

Hariman, R., \& Lucaites, J. L. (2016). The public image: Photography and civic spectatorship. Chicago, IL: University of Chicago Press.

Hermida, A. (2010). Twittering the News: The emergence of ambient journalism. Journalism Practice, 4 (3), 297-308. doi: 10.1080/17512781003640703 
Hermida, A., Lewis, S. C., \& Zamith, R. (2014). Sourcing the Arab Spring: A Case Study of Andy Carvin's Sources on Twitter During the Tunisian and Egyptian Revolutions. Journal of ComputerMediated Communication, 19 (3), 479-499. doi: 10.1111/jcc4.12074

Howard, P. N., Duffy, A., Freelon, D., Hussain, M. M., Mari, W., \& Maziad, M. (2011). Opening Closed Regimes: What Was the Role of Social Media During the Arab Spring? (SSRN Scholarly Paper No. ID 2595096; 1-30). Rochester, NY: Social Science Research Network. Retrieved from Social Science Research Network website: https://papers.ssrn.com/abstract=2595096

Lewis, S. C. (2012). The Tension Between Professional Control and Open Participation: Journalism and its boundaries. Information, Communication \& Society, 15 (6), 836-866. doi: 10.1080/1369118X.2012.674150

Lotan, G., Graeff, E., Ananny, M., Gaffney, D., Pearce, I., \& others. (2011). The Arab Spring| the revolutions were tweeted: Information flows during the 2011 Tunisian and Egyptian revolutions. International Journal of Communication, 5 (31).

Machin, D., \& Polzer, L. (2015). Visual journalism. Bloomsburry: Macmillan Red Globe Press.

Mortensen, M. (2015). Conflictual Media Events, Eyewitness Images, and the Boston Marathon Bombing (2013). Journalism Practice, 9 (4), 536-551. doi: 10.1080/17512786.2015.1030140

N., N. (2020, April 1). Math teacher brings over whiteboard to help student through glass door. Retrieved 27 May 2021, from Fox13News website: https://www.fox13news.com/news/math-teacherbrings-over-whiteboard-to-help-student-through-glass-door

Newton, Julianne H. (2009). Photojournalism: Do people matter? Then photojournalism matters. Journalism Practice, 3 (2), 233-243. doi: 10.1080/17512780802681363

Newton, Julianne H. (2012). The burden of visual truth: The role of photojournalism in mediating reality. New York, NY; London: Routledge.

Paybarah, A., \& Negroni, C. (2019, October 2). B-17 Plane From World War II Crashes at Bradley Airport, Killing at Least 7-The New York Times. Retrieved 27 May 2021, from New York Times website: https://www.nytimes.com/2019/10/02/nyregion/plane-crash.html

Peters, C., \& Allan, S. (2016). Everyday imagery: Users reflections on smartphone cameras and communication. Convergence: The International Journal of Research into New Media Technologies. doi: $10.1177 / 1354856516678395$

Rauchfleisch, A., Artho, X., Metag, J., Post, S., \& Schäfer, M. S. (2017). How journalists verify usergenerated content during terrorist crises. Analyzing Twitter communication during the Brussels attacks. Social Media+ Society, 3 (3), 1-13. doi: 0.1177/2056305117717888

Rubinstein, D., \& Sluis, K. (2008). A LIFE MORE PHOTOGRAPHIC: Mapping the networked image. Photographies, 1 (1), 9-28. doi: 10.1080/17540760701785842

Runge, E. (2012). Glamour des Elends: Ethik, Ästhetik und Sozialkritik bei Sebastião Salgado und Jeff Wall. Böhlau, Köln.

Runge, E. (2020a). The Travels of Photographs Within the Global Image Market. How Monopolisation, Interconnectedness, and Differentiation Shape the Economics of Photography. Photographies, 13 (3), 365-384. doi: 10.1080/17540763.2020.1774917 
Runge, E. (2020b). Visuelle Weltbürgerschaft der Fotografie. Visual History. doi: doi.org/10.14765/zzf.dok-1816

Runge, E. (2021a). Para-Fotojournalismus: Vernetzte Bilder zwischen Profession und Partizipation. Zur Theorie des digitalen Bildes. Medienwissenschaft: Rezensionen, (2).

Runge, E. (2021b). SnAppShots: Fotojournalismus auf Twitter - Zwischen privater Fotografie und Ware für Fotoagenturen. In J. Schühle \& U. Hägele (Eds.), Visuelle Kultur. Studien und Materialien. Münster: Waxmann Verlag.

Taft, S. (2014, December 27). How did you help us change the way we report the news? BBC News. Retrieved from https://www.bbc.com/news/world-30421631

Toffler, A. (1996). The Third Wave. New York: Bantam Books.

Williams, A., Wardle, C., \& Wahl-Jorgensen, K. (2011). "HAVE THEY GOT NEWS FOR US?": Audience revolution or business as usual at the BBC? Journalism Practice, 5 (1), 85-99. doi: $10.1080 / 17512781003670031$

Zelizer, B. (2007). On "Having Been There": "Eyewitnessing" as a Journalistic Key Word. Critical Studies in Media Communication, 24 (5), 408-428. doi: 10.1080/07393180701694614

\section{Original received at: 10 June 2021}

Accepted for publication in: 05 July 2021

\section{Evelyn Runge}

Evelyn Runge, Dr. phil., is Principal Investigator and Assistant Professor at the Institute of Media Culture and Theatre at Cologne University in Germany. Her research project „Behind the Digital Image“ investigates the digital image by using mixed methods, especially media ethnography and digital methods (funded by the Deutsche Forschungsgemeinschaft (DFG, German Research Foundation, Grant 421462167). Since 2018, Dr. Runge acts as Vice-Chair of ECREA's Journalism Section. Twitter: @evisualyn. ORCID: http://orcid.org/0000-0001-9622-2393

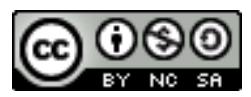

This work is licensed with a License

Creative Commons Attribution-NonCommercial-ShareAlike 4.0 International 